\title{
Ongoing declines of woodland birds: Are restoration plantings making a difference?
}

\author{
Donna J. Belder (D) $1,2,3,6$ Jennifer C. Pierson, ${ }^{1,4}$ Ashwin C. Rudder, ${ }^{3}$ and David B. Lindenmayer (D) 1,2,5 \\ ${ }^{1}$ Fenner School of Environment and Society, The Australian National University, Canberra, Australian \\ Capital Territory 2601 Australia \\ ${ }^{2}$ National Environmental Science Program Threatened Species Recovery Hub, The Australian National University, Canberra, \\ Australian Capital Territory 2601 Australia \\ ${ }^{3}$ Australian Wildlife Conservancy, PO Box 8070, Subiaco East, Western Australia 6008 Australia \\ ${ }^{4}$ ACT Parks and Conservation Service, Environment, Planning and Sustainable Development Directorate, ACT Government, Canberra, \\ Australian Capital Territory 2602 Australia \\ ${ }^{5}$ Sustainable Farms, The Australian National University, Canberra, Australian Capital Territory 2601 Australia
}

Citation: Belder, D. J., J. C. Pierson, A. C. Rudder, and D. B. Lindenmayer. 2021. Ongoing declines of woodland birds: Are restoration plantings making a difference? Ecological Applications 31(3):e02268. 10. 1002/eap. 2268

Abstract. Woodland birds are a species assemblage of conservation concern, and their persistence in fragmented agricultural landscapes is dependent on both the preservation of existing woodland remnants and the implementation of restoration plantings. However, little is known about the habitat-use and persistence of birds in fragmented agricultural landscapes. We present a detailed, population-oriented study of woodland birds in temperate eucalypt woodland restoration plantings and remnant woodland patches in the South-west Slopes bioregion of New South Wales, Australia. First, we undertook a 3-yr mark-recapture project to assess annual survival and site fidelity in restoration plantings and woodland remnants. We supplemented our recapture efforts with resightings of color-banded individuals. Second, we tracked individual birds of two species, Superb Fairywren (Malurus cyaneus) and Willie Wagtail (Rhipidura leucophrys), and documented snapshots of their home ranges and movement patterns during the breeding season. Annual survival in the woodland bird assemblage was lower than expected (51\%). Home ranges of the Superb Fairywren were positively correlated with patch size, and were constrained by patch edges in linear sites. Superb Fairywrens and Willie Wagtails were more likely to travel longer distances between substrates while foraging in linear sites. Willie Wagtails engaged in significant gap-crossing (up to $400 \mathrm{~m}$ ) between adjacent habitat patches. Our findings indicate that (1) patch isolation and certain patch configurations place resident birds at an energetic disadvantage, and (2) in our study area, woodland bird populations are continuing to decline. We recommend landscape-scale habitat restoration programs aim to address ongoing population declines. Studies such as ours conducted over longer time periods would provide a deeper understanding of habitat use and population processes of woodland birds in fragmented agricultural landscapes.

Key words: animal movement; mark-recapture; population dynamics; ringing; territory.

\section{INTRODUCTION}

Habitat loss, fragmentation, and degradation resulting from agricultural expansion are leading causes of biodiversity declines worldwide (Newbold et al. 2015, Molotoks et al. 2018). The current rate of global biodiversity loss has been described as "catastrophic" (Driscoll et al. 2018), with experts fearing we have entered a sixth global mass extinction event (Barnosky et al. 2011, Ceballos et al. 2015). As such, there has been an increase in ecological restoration efforts to combat habitat loss and fragmentation (Menz et al. 2013, Barral et al. 2015). An

Manuscript received 11 November 2019; revised 4 June 2020; accepted 16 August 2020. Corresponding Editor: Dianne Brunton.

${ }^{6}$ E-mail: donna.belder@anu.edu.au example is the establishment of "restoration plantings" in agricultural landscapes: patches of replanted native vegetation in areas that have been previously cleared for agriculture.

In southern Australia, the recovery of woodland birds is a common objective of restoration plantings, as this group has suffered substantial and ongoing population declines due to habitat loss and fragmentation (Freudenberger 2001, Rayner et al. 2014). Several studies have identified a number of woodland bird species that preferentially occupy restoration plantings over woodland remnants (Barrett et al. 2008, Cunningham et al. 2008, Lindenmayer et al. 2010b). However, the vast majority of previous studies have used pattern data, such as presence and abundance, to draw conclusions about the suitability of habitat for woodland birds (Belder et al. 2018). 
Little is known about the long-term population responses and habitat-use of woodland birds in restoration plantings, and in fragmented agricultural landscapes more generally.

An understanding of population processes, including survival and site fidelity, is crucial for effective management of woodland bird populations (McKibbin and Bishop 2012, Belder et al. 2018). Survival is a key indicator of the extent to which restoration plantings and woodland remnants are providing suitable habitat for woodland birds. If survival is low, habitat patches may be acting as population sinks or ecological traps (Dias 1996, Battin 2004). Site fidelity also provides insights into the relative importance of individual habitat patches for animal populations (McKibbin and Bishop 2012, Meager et al. 2018). If site fidelity is high, managers might allocate resources to maintain or improve habitat quality in targeted areas (Lehnen and Rodewald 2009). However, if site fidelity is low, a landscape-scale approach to habitat restoration and management may be needed (Schlossberg 2009).

In conjunction with demographic parameters such as survival and site fidelity, examining home ranges and movement patterns of individuals can provide insights into habitat quality and resource use. For example, the formation of smaller home ranges within a contiguous area typically indicates higher quality habitat (Ford 1983). Restoration plantings present an interesting paradox: many bird species will preferentially occupy plantings, but many plantings are narrow, linear windbreaks that are not conducive to optimal foraging according to established theories (Ford 1983, Stephens 2008). This may disproportionately affect species that are not highly mobile or not willing to cross habitat gaps (Van Houtan et al. 2007, Lees and Peres 2009). Assessing the effects of patch geometry and configuration on home ranges and movements of woodland birds may further assist with conservation planning and management.

\section{Research objectives}

The primary aim of this paper was to investigate whether restoration plantings are providing quality habitat to support woodland bird populations in fragmented agricultural landscapes. We used two indicators of habitat quality: annual survival/site fidelity and home range attributes (size, shape).

We first sought to quantify annual survival and site fidelity in our study region. We predicted that survival and site fidelity in restoration plantings would be high, as we have $20 \mathrm{yr}$ of survey data in our study region suggesting that woodland birds readily occupy restoration plantings (Lindenmayer et al. 2018). We expected that birds in woodland remnants would show even higher survival and site fidelity, as these patches are typically considered to support a wider range of species than restoration plantings (Cunningham et al. 2008, Ikin et al. 2018). In addition, most of the species chosen for our study are sedentary, and long-distance movements are not commonly reported (Australian Bird and Bat Banding Scheme 2016). In general, we expected high survival estimates. This is because many species of Australian birds are long lived compared to their similarly sized northern hemisphere counterparts; life spans of $20+\mathrm{yr}$ have been recorded for many species (Yom-Tov et al. 1992, Australian Bird and Bat Banding Scheme 2016). A high survival rate should be expected for Australian woodland bird species if the habitat is suitable.

In addition to quantifying survival and site fidelity, we posed the following specific research questions:

\section{Question 1. Do patch attributes (type, size, shape) influence survival and site fidelity of woodland birds in fragmented agricultural landscapes?}

We expected survival and site fidelity to be higher in block-shaped sites than in linear sites. This is because previous studies have indicated that block-shaped sites support a greater diversity and abundance of woodland bird species than what is supported by linear sites (Lindenmayer et al. 2007). Previous research has also linked patch size to habitat quality in fragmented agricultural landscapes, with many studies recommending that restoration plantings should be as large as possible to maximize biodiversity benefits (Freudenberger et al. 2004, Lindenmayer et al. 2010b, Cunningham et al. 2015). We therefore predicted that survival and site fidelity would be higher in larger sites than in smaller sites.

Question 2. How do patch attributes influence the movement patterns of birds, including the size and shape of home ranges?

We predicted that home ranges would be smaller in reference sites than in restoration plantings and similarly sized woodland remnants. This is because reference areas present a contiguous area of suitable habitat in which birds can establish a territory. When resources are patchily distributed, as they are in fragmented habitats, birds may need to move greater distances through the landscape to obtain sufficient resources (Ford 1983, Hinsley et al. 2008).

We expected the home ranges of individuals in blockshaped sites to be more compact and rounded than those in linear sites. This is because optimal foraging theory favors the formation of a more uniform home range shape (Andersson 1978, Dill 1978). This is especially relevant during the breeding season, when optimal central place foraging is a key determinant of home range size and shape (Andersson 1981, Kacelnik 1984, Rosenberg and McKelvey 2016). Optimal central place foraging is foraging away from a key central point, such as the prime habitat within a defended territory, or an active nest (Stephens 2008). 
We predicted that birds in linear sites would travel longer average distances between distinct substrates within their territories. We also expected birds in smaller and more linear sites to engage in more gap-crossing behavior than those in larger and more block-shaped sites.

\section{Methods}

\section{Study area}

We conducted our study in the South-west Slopes bioregion of New South Wales (NSW), Australia. It is the most cleared and fragmented bioregion in NSW, with at least $85 \%$ of the native temperate woodland vegetation having been cleared for agriculture since European settlement (Lindenmayer et al. 2010a, Benson 2013). Remnant patches persist as highly fragmented patches among a matrix of pasture and cropland, some as small as a single, isolated "paddock tree" (Lindenmayer et al. 2010a, Lindenmayer 2017). The majority of remnant vegetation persists on private land, and larger areas are predominantly on unproductive land such as rocky ridgetops. The dominant ecological community is white box (Eucalyptus albens)/yellow box (E. melliodora)/Blakely's red gum (E. blakelyi) grassy woodland, which is federally listed as critically endangered (Department of the Environment and Energy 2018). Patches of red stringybark (E. macrorhyncha) woodland and mugga ironbark (E. sideroxylon) woodland are also present. To address habitat loss, restoration plantings have been implemented on farms throughout the Southwest Slopes bioregion (Lindenmayer et al. 2013). Woodland habitat in the study region is crucial for the persistence of several threatened bird species, including the critically endangered Regent Honeyeater (Anthochaera phrygia) and Swift Parrot (Lathamus discolor).

The South-west Slopes has a mild temperate climate, with warm to hot summers (January mean maximum temperature $31.5^{\circ} \mathrm{C}$ ) and cool to cold winters (July mean maximum temperature $11.9^{\circ} \mathrm{C}$; Bureau of Meteorology 2019). Mean annual rainfall is $572 \mathrm{~mm}$, and rainfall is distributed fairly evenly throughout the year (Bureau of Meteorology 2019). Rainfall in the study area was above average during the first two years of this study, and below average during the third year (Bureau of Meteorology 2019).

\section{Study sites}

We used long-term bird survey data (see Lindenmayer et al. 2010b) to select a subset of sites in which to conduct our study (Fig. 1). We selected 12 restoration plantings and six similarly sized woodland remnants of varying size (1.3-7.7 ha) and shape (linear vs. blockshaped; calculated numerically as perimeter/width). We additionally chose three large ( $>47$ ha) remnant patches of woodland to serve as reference sites, representing good quality woodland in the study area. Site attributes are detailed in Appendix S6: Table S1.

We chose sites with low abundances of the Noisy Miner (Manorina melanocephala), a hyperaggressive native honeyeater that is known to exclude small woodland birds (Maron et al. 2013, Bennett et al. 2015, Beggs et al. 2019). While we acknowledge the significance of the Noisy Miner's influence on woodland birds, minimizing its presence in our study sites enabled us to focus on our questions of interest. Our sites were separated geographically by a minimum of $500 \mathrm{~m}$ to promote spatial independence.

Restoration plantings were aged between 12 and $25 \mathrm{yr}$, and were characterized by a Eucalyptus overstorey and an understorey of predominantly Acacia shrubs. Trees and shrubs were planted for ecological purposes, and were usually fenced for protection from grazing by livestock (Appendix S6). Remnant woodland patches typically constituted a Eucalyptus overstorey plus an Acacia-dominated understorey of varying density. Remnant sites tended to contain more coarse woody debris (fallen branches and trees) than restoration plantings. All sites featured a ground layer that was usually dominated by exotic pasture grasses, with various amounts of leaf litter, native forbs, native grasses, weeds, bare ground, moss/lichens, rocks, and coarse woody debris.

\section{Bird banding and recaptures}

We undertook initial banding of woodland birds in July-October of 2015. Subsequent recapture and banding efforts took place in June-August of 2016 and 2017. We conducted an approximately equal number of net hours in each study site, with sites selected based on suitable habitat features and observed passage routes to maximize capture rates. Once selected, we used the same sites consistently throughout the three years of the study, except when vegetation growth or tree collapse prevented the use of existing net sites. In these cases, we moved nets to suitable locations as close as possible to the original netted sites. We used two nets that were $6 \mathrm{~m}$ in length, and four nets that were $9 \mathrm{~m}$ in length. We banded over two consecutive days in each study site. On the first day, we operated nets for approximately four hours pre-sunset. On the subsequent day, we opened nets from $0.5 \mathrm{~h}$ pre-dawn to approximately $4 \mathrm{~h}$ post-sunrise. Inclement weather sometimes required us to close nets, and occasionally prevented us from banding on consecutive days in our study sites. In these instances, we resumed banding at the earliest opportunity once the weather had cleared.

We banded birds with a standard metal band (aluminum or aluminum alloy) provided by the Australian Bird and Bat Banding Scheme. Ten species also received a combination of colored plastic and/or metal leg bands. These were the Superb Fairywren (Malurus cyaneus), Yellow-rumped Thornbill (Acanthiza chrysorrhoa), Buff- 


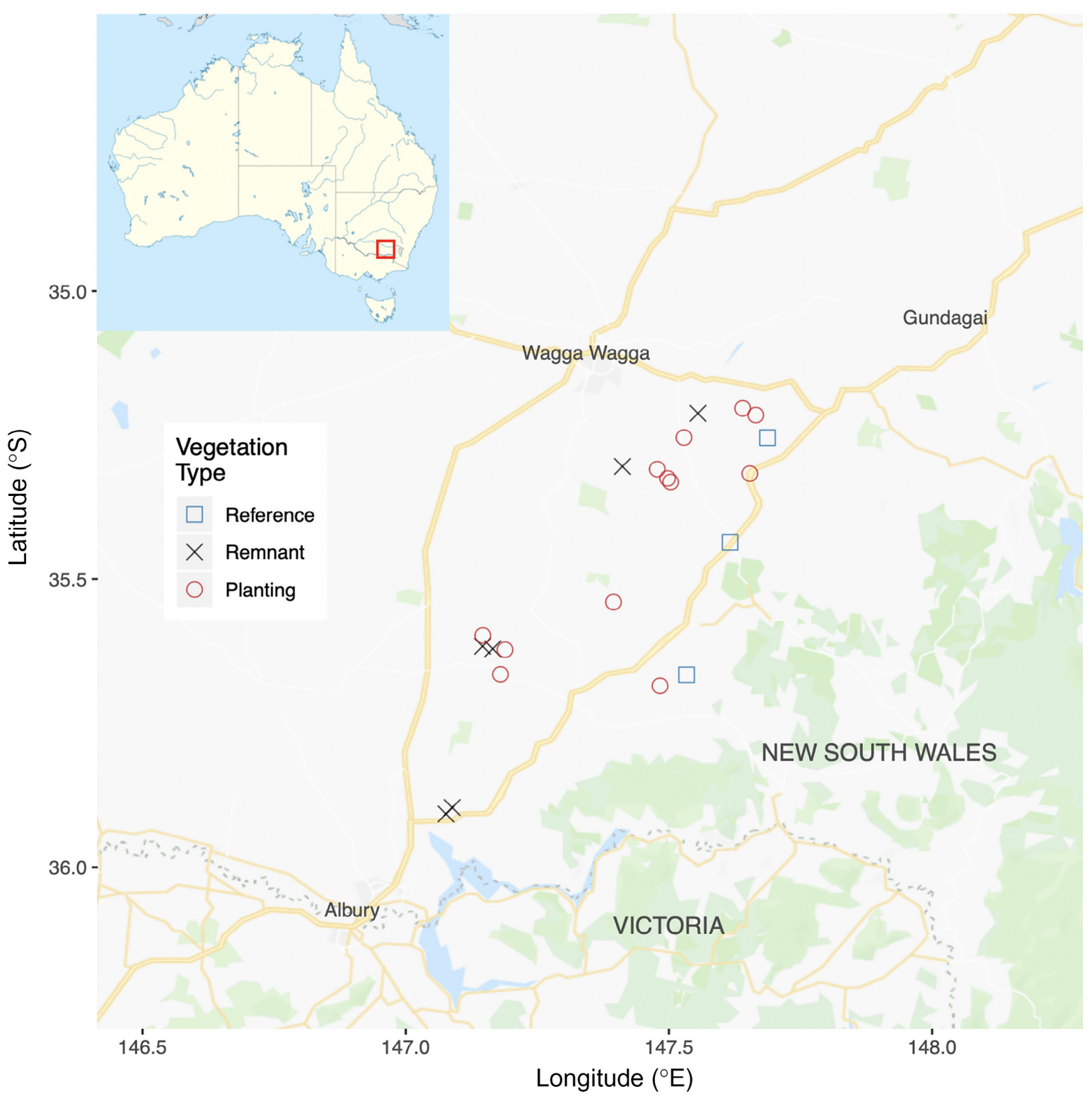

FIG. 1. Location of study sites in the South-west Slopes bioregion of New South Wales, Australia. Map created using ggmap for R (Kahle and Wickham 2013).

rumped Thornbill (A. reguloides), Grey Shrikethrush (Colluricincla harmonica), Rufous Whistler (Pachycephala rufiventris), Red-capped Robin (Petroica goodenovii), Willie Wagtail (Rhipidura leucophrys), Whitebrowed Babbler (Pomatostomus superciliosus), Speckled Warbler (Pyrrholaemus sagittatus), and Diamond Firetail (Stagonopleura guttata). We released birds within $300 \mathrm{~m}$ of their initial capture site. Any juveniles captured were released as close as possible to their initial capture site.

For the purposes of our study, the "woodland assemblage" included all species that were captured in our study sites (Appendix S1).

\section{Resightings}

In the breeding season of 2015 (September-December), we recorded incidental sightings of color-banded birds. In 2016, we undertook surveys to record sightings of color-banded individuals. We undertook random area searches in each study site, with the length of time designated per unit area. We surveyed small sites (1.4 ha search area) for one hour, and large sites (3 ha search area) for two hours. A skilled observer searched a patch for woodland birds, and recorded color-band combinations and GPS locations of color-banded individuals when sighted. Sites were surveyed once per month from 
September to November. We also recorded incidental sightings of color-banded individuals while visiting study sites throughout the breeding season.

The seasonally migratory rufous whistler had not yet returned to the study region when recapture efforts took place in 2016 and 2017. We resighted color-banded individuals incidentally in 2015, and during thorough site surveys in 2016 (see Belder et al. 2019). In 2017, we undertook targeted surveys to identify whether colorbanded Rufous Whistlers had returned to their territories. We visited known territories of color-banded males in October 2017 and used call-playback for up to $5 \mathrm{~min}$ utes to elicit a territorial response. If a whistler responded, we immediately ceased playback and followed the bird until we could ascertain its band status/combination.

\section{Home range tracking}

We chose two target species for home range tracking: the Superb Fairywren and the Willie Wagtail. Both species are relatively common in habitat patches in agricultural landscapes, and can use the matrix to some extent (usually foraging at the edges of patches). However, the two species differ in their movement patterns and habitat preferences (Menkhorst et al. 2017). Additional reasons for choosing these two species included their bold nature, and their ease of detection (facilitating tracking of individuals).

Superb Fairywrens were fitted with colored leg bands for ease of tracking and identification. For consistency, we tracked only male Fairywrens. Not all tracked Willie Wagtails had been banded. However, the low density of Willie Wagtails in the study sites, their preference for open habitats, and the presence of individually distinct plumage or feather molt characteristics enabled us to reliably track individual birds over the course of several hours.

We selected birds to track at random. Upon arriving at a study site, an observer would locate an individual (typically the first bird encountered) on which to focus. Based on a pilot study in 2015, we determined that a minimum of 30 home range points was required to map a representative snapshot of the home range of a male Superb Fairywren or a Willie Wagtail. We therefore followed birds until at least 30 points had been recorded. We followed birds for a maximum of $4 \mathrm{~h}$.

We used a handheld Garmin eTrex GPS device (Schaffhausen, Switzerland), accurate to the nearest $3 \mathrm{~m}$, to record home range data. Observers typically watched birds from a distance of around $20 \mathrm{~m}$, using a pair of handheld binoculars, so as to not disrupt or influence the behavior or movements of the birds. Observers also waited until a bird had moved away from each distinct substrate before approaching to record the GPS location.

\section{Statistical analyses}

Survival and site fidelity.-To analyze recapture and resighting data, we used Program MARK (White and
Burnham 1999) via the R package RMark (Laake 2013) in $\mathrm{R}$ version 3.5.2 ( $\mathrm{R}$ Core Team 2019). We used the Cormack-Jolly-Seber (CJS) model (Lebreton et al. 1992) to estimate apparent survival $(\phi)$ for the entire assemblage. For color-banded birds, and for the Superb Fairywren, we also used the Barker model (Barker 1997) to estimate survival and site fidelity. This model allows the inclusion of ad hoc resightings of color-marked individuals, separates permanent emigration from true mortality, and relaxes the assumption of no permanent emigration. These modifications permit the calculation of an apparent survival estimate $(S)$ that approaches true survival (Schwarzer et al. 2012, Barbour et al. 2013). Model parameters as described by Schwarzer et al. (2012) are as follows: $S_{i}$, survival; $p_{i}$, recapture probability (the probability that an animal at risk of capture at time $i$ is captured); $r_{i}$, the probability that an animal dies, is found and reported dead between time $i$ and time $i+1$; $R_{i}$, resighting probability (the probability that an animal is resighted between time $i$ and $i+1) ; R_{i}^{\prime}$, the probability that an animal dies between time $i$ and $i+1$, but is resighted alive before it dies; $F_{i}$, fidelity (the probability that an animal at risk of capture at time $i$ is at risk of capture at $i+1) ; F_{i}^{\prime}$, return (the probability that an animal not at risk of capture at time $i$ is at risk of capture at $i+1)$.

As we recovered only one dead bird during our study, model outputs for $r_{i}$ and $R_{i}^{\prime}$ were not interpretable. We therefore set these parameters to 0 in all models.

We tested candidate models against a null model that assumed all parameters were constant except those fixed at zero (Table 1). Variables of interest were site type, size, and shape. To address overdispersion, we ranked candidate models by $\mathrm{QAIC}_{\mathrm{c}}$ adjusted by the variance inflation factor $(\hat{c})$ of the global model. We considered models with $\Delta$ QAIC $_{\mathrm{c}} \leq 2$ to be top-ranked models. We obtained two parameter estimates for each subset: the estimate from the top-ranked model, and model-averaged estimates from the top-ranked models. We used the package MuMIn (Bartoń 2018) in conjunction with RMark to conduct model averaging.

Home ranges and movement analyses. - We used ArcMap Desktop version 10.6.1 (ESRI 2018) to plot GPS coordinates of home ranges. We used the Minimum Bounding Geometry function to calculate $100 \%$ Minimum Convex Polygons (MCPs) for all home ranges. We also calculated the perimeter and width of each home range. Additionally, we calculated the distance moved by individual birds between distinct substrates (GPS points) during a tracking period, and documented "gap-crossing" behavior. We defined "substrates" as distinct units of vegetation (individual trees, shrubs), woody debris (logs, fallen branches), artificial substrates (fence wires, posts), and patches of ground on which a bird perched or foraged. We defined gaps as spaces between patches of native vegetation. A "patch" of native vegetation may comprise a single paddock tree. 
TABle 1. Parameters modeled with Cormack-Jolly-Seber (CJS) and Barker survival models.

\begin{tabular}{|c|c|}
\hline Model description & Parameters \\
\hline Basic CJS model & $\phi() p.()$. \\
\hline \multicolumn{2}{|l|}{ Survival } \\
\hline Constant & $\phi()$. \\
\hline Site type & $\phi($ type $)$ \\
\hline Site size & $\phi($ size $)$ \\
\hline Site shape & $\phi($ shape $)$ \\
\hline \multicolumn{2}{|l|}{ Recapture } \\
\hline Constant & $p()$. \\
\hline Site type & $p$ (type) \\
\hline Site size & $p($ size $)$ \\
\hline Site shape & $p$ (shape) \\
\hline Basic Barker model & $S() p.() r.() R.(.) R^{\prime}() F.(.) F^{\prime}$ (.) \\
\hline \multicolumn{2}{|l|}{ Survival } \\
\hline Constant & $S()$. \\
\hline Site type & $S$ (type) \\
\hline Site size & $S($ size $)$ \\
\hline Site shape & $S$ (shape) \\
\hline \multicolumn{2}{|l|}{ Recapture } \\
\hline Constant & $p()$. \\
\hline Site type & $p$ (type) \\
\hline Site size & $p($ size $)$ \\
\hline Site shape & $p$ (shape) \\
\hline \multicolumn{2}{|l|}{ Recovery } \\
\hline No dead recoveries & fixed at 0 \\
\hline \multicolumn{2}{|l|}{ Resighting } \\
\hline Constant & $R()$. \\
\hline \multicolumn{2}{|l|}{ Resighting } \\
\hline No dead recoveries & fixed at 0 \\
\hline \multicolumn{2}{|l|}{ Fidelity } \\
\hline Constant & $F()$. \\
\hline Site type & $F($ type $)$ \\
\hline Site size & $F($ size $)$ \\
\hline Site shape & $F$ (shape) \\
\hline \multicolumn{2}{|l|}{ Return parameter } \\
\hline Constant & $F^{\prime}()$. \\
\hline
\end{tabular}

Notes: $\phi$ represents survival estimate from CJS models. $S$ represents survival estimate from Barker models. Table adapted from Kauffman et al. (2003).

We used linear regression to model home range size and shape against patch attributes (type, size, shape, planting age; Table 2). Home range size was log-transformed to improve model fit. We also modeled the average distance moved by individual birds between distinct substrates against patch attributes. Additionally, we investigated whether patch attributes influenced the occurrence of long-distance movements between substrates (movements approximately four times the average distance moved; $>50 \mathrm{~m}$ in Superb Fairywrens and $>100 \mathrm{~m}$ in Willie Wagtails). For the latter analyses, we used linear mixed-effects regression models with individual bird as a random effect. We used a reciprocal transformation on movement distance to improve model fit. We obtained parameter estimates from the top-ranked
TABLE 2. Linear regression and linear mixed effects regression model parameters.

\begin{tabular}{|c|c|c|}
\hline Variable name & Variable type & Description \\
\hline TERRSIZE & response & home range size (ha) \\
\hline TERRSHAPE & response & $\begin{array}{l}\text { measure of home range shape, } \\
\text { calculated as perimeter/ } \\
\text { width }(\mathrm{m})\end{array}$ \\
\hline DIST & response & $\begin{array}{l}\text { distance moved between } \\
\text { substrates }(\mathrm{m})\end{array}$ \\
\hline TYPE & predictor & $\begin{array}{l}\text { patch type (planting, } \\
\text { remnant, reference) }\end{array}$ \\
\hline SIZE & predictor & patch size (ha) \\
\hline SHAPE & predictor & $\begin{array}{l}\text { measure of patch shape, } \\
\text { calculated as perimeter/ } \\
\text { width }(\mathrm{m})\end{array}$ \\
\hline AGE & predictor & $\begin{array}{l}\text { age of planting at the } \\
\text { commencement of the } \\
\text { study (yr) }\end{array}$ \\
\hline BIRD & random effect & identity of tracked bird \\
\hline
\end{tabular}

models. We used the R package lme4 (Bates et al. 2015) to conduct linear mixed effects regression.

\section{RESULTS \\ General}

We banded 1,261 woodland birds, comprising 38 species, over the duration of the study. The most commonly caught species were the Superb Fairywren, Yellow-rumped Thornbill, Yellow Thornbill, Red-browed Finch, and Flame Robin (Appendix S1: Table S1). Our banding and recapture data are summarized in full in Appendix S1.

\section{Survival and site fidelity}

Of the 943 individuals banded during the first two years of the study, 386 , or $40.9 \%$, were recaptured or resighted at least once over the duration of the study. We achieved recapture rates of $18.3 \%$ and $6.8 \%$ in 2016 and 2017, respectively.

Annual survival estimates for the woodland assemblage according to CJS were $51 \%$ ( $\mathrm{SE}=8 \%$; Tables 3, 4). Survival estimates from Barker models for colorbanded birds and the Superb Fairywren were higher than estimates from CJS models (Tables 3, 4). Barker survival estimates were $55 \%(\mathrm{SE}=2 \%)$ for color-banded birds, and $55 \%(\mathrm{SE}=3 \%)$ for the Superb Fairywren (Tables 3, 4). CJS and Barker estimates changed only slightly for each subset when reference sites were excluded from analyses. Although site attributes (type, size, shape) appeared in several top-ranked candidate models (Appendix S2), the null model was the best-fitted model in every instance.

Site fidelity estimates from Barker models for both color-banded birds and the Superb Fairywren had very large confidence intervals, and were therefore not interpretable. However, a noteworthy finding was that a large 
TABLE 3. Survival estimates for birds in restoration plantings, similarly sized woodland remnants, and large reference sites.

\begin{tabular}{|c|c|c|c|c|}
\hline \multirow[b]{2}{*}{ Parameter } & \multirow[b]{2}{*}{ Estimate } & \multirow[b]{2}{*}{ SE } & \multicolumn{2}{|c|}{$95 \% \mathrm{CI}$} \\
\hline & & & Lower & Upper \\
\hline \multicolumn{5}{|c|}{ Woodland assemblage } \\
\hline$\phi()$. & 0.5109 & 0.0831 & 0.3524 & 0.6673 \\
\hline \multicolumn{5}{|c|}{ Color-banded birds } \\
\hline$\phi()$. & 0.4672 & 0.0792 & 0.3197 & 0.6206 \\
\hline$S()$. & 0.5538 & 0.0233 & 0.5078 & 0.5989 \\
\hline \multicolumn{5}{|c|}{ Superb Fairywren (Malurus cyaneus) } \\
\hline$\phi()$. & 0.4007 & 0.0729 & 0.2693 & 0.5482 \\
\hline$S()$. & 0.5491 & 0.0313 & 0.4874 & 0.6094 \\
\hline
\end{tabular}

Notes: Estimates are taken from the best-fitted models for each subset. The null model was the best-fitted model in all instances.

TABLE 4. Survival estimates for birds in restoration plantings and similarly sized woodland remnants (excluding large reference sites).

\begin{tabular}{|c|c|c|c|c|}
\hline \multirow[b]{2}{*}{ Parameter } & \multirow[b]{2}{*}{ Estimate } & \multirow[b]{2}{*}{ SE } & \multicolumn{2}{|c|}{$95 \% \mathrm{CI}$} \\
\hline & & & Lower & Upper \\
\hline \multicolumn{5}{|c|}{ Woodland assemblage } \\
\hline \multicolumn{5}{|c|}{ Best-fitted model } \\
\hline$\phi()$. & 0.5156 & 0.0880 & 0.3480 & 0.6798 \\
\hline \multicolumn{5}{|c|}{ Model average } \\
\hline$\phi$ & 0.5139 & 0.0877 & 0.3469 & 0.6778 \\
\hline \multicolumn{5}{|c|}{ Color-banded birds } \\
\hline \multicolumn{5}{|c|}{ Best-fitted model } \\
\hline$\phi()$. & 0.4780 & 0.0847 & 0.3201 & 0.6404 \\
\hline$S()$. & 0.5451 & 0.0241 & 0.4975 & 0.5919 \\
\hline \multicolumn{5}{|c|}{ Model average } \\
\hline$\phi$ & 0.4767 & 0.0846 & 0.3190 & 0.6392 \\
\hline$S$ & 0.5450 & 0.0242 & 0.4974 & 0.5919 \\
\hline \multicolumn{5}{|c|}{ Superb Fairywren (Malurus cyaneus) } \\
\hline \multicolumn{5}{|c|}{ Best-fitted model } \\
\hline$\phi()$. & 0.4190 & 0.0792 & 0.2759 & 0.5772 \\
\hline$S()$. & 0.5459 & 0.0321 & 0.4826 & 0.6077 \\
\hline \multicolumn{5}{|c|}{ Model average } \\
\hline$\phi$ & 0.4163 & 0.0788 & 0.2741 & 0.5739 \\
\hline$S$ & 0.5460 & 0.0323 & 0.4823 & 0.6083 \\
\hline
\end{tabular}

Notes: Estimates from the best-fitted model and model-averaged estimates are provided for each subset. The null model was the best-fitted model in all instances.

proportion of banded male Rufous Whistlers returned to the study sites. Of the nine males banded in 2015, seven returned in 2016 to defend the territories in which they were banded, and five returned again in 2017. Of the birds present in three consecutive years, four were in plantings, and one was in a woodland remnant. Interestingly, all of these plantings were linear in shape.

\section{Home ranges}

General.-We mapped home ranges for 45 Superb Fairywrens and 30 Willie Wagtails (Table 5). These were
TABLE 5. Home range ( $100 \%$ minimum convex polygon; mean $\pm \mathrm{SE}$ ) of birds tracked in restoration plantings, woodland remnants, and large reference sites in the South-west Slopes bioregion of New South Wales, Australia.

\begin{tabular}{lrrcr}
\hline \hline & & \multicolumn{2}{c}{ Home range (ha) } & \\
\cline { 3 - 4 } Patch type & $n$ & Mean \pm SE & Range & No. waypoints \\
\hline $\begin{array}{l}\text { Malurus } \\
\text { cyaneus }\end{array}$ & & & & \\
$\quad$ Planting & 30 & $0.30 \pm 0.04$ & $0.08-0.92$ & $92 \pm 10$ \\
$\quad$ Remnant & 11 & $0.48 \pm 0.16$ & $0.08-1.57$ & $110 \pm 17$ \\
$\quad$ Reference & 4 & $0.60 \pm 0.18$ & $0.27-1.05$ & $105 \pm 41$ \\
$\quad$ All & 45 & $0.37 \pm 0.05$ & $0.08-1.57$ & $97 \pm 8$ \\
$\begin{array}{l}\text { Rhipidura } \\
\text { leucophrys }\end{array}$ & & & & \\
$\quad$ Planting & 15 & $2.32 \pm 0.54$ & $0.48-8.62$ & $91 \pm 14$ \\
$\quad$ Remnant & 11 & $1.37 \pm 0.24$ & $0.16-2.81$ & $94 \pm 14$ \\
$\quad$ Reference & 4 & $3.09 \pm 0.92$ & $1.30-5.63$ & $92 \pm 15$ \\
$\quad$ All & 30 & $2.07 \pm 0.32$ & $0.16-8.62$ & $92 \pm 9$ \\
\hline
\end{tabular}

distributed among the 12 restoration plantings, six woodland remnants, and three reference sites. We mapped at least one Superb Fairywren home range in each site, and at least one Willie Wagtail home range in a site that corresponded to each treatment type. On average, we obtained approximately equal numbers of waypoints for each tracked bird (Table 5).

Home ranges. - There was relatively little variation in home range size among the 45 Fairywrens we tracked (Table 5). In comparison, home ranges of the Willie Wagtail were highly variable across all site types (Table 5).

Home ranges of Superb Fairywrens were significantly larger in reference sites than in restoration plantings and similarly sized woodland remnants (Table 6; Fig. 2). When assessing the effects of patch size and shape in the latter two site types (i.e., excluding large reference sites), we found that home range size was positively correlated with patch size (Table 6). The same was true in restoration plantings alone (Table 6). We did not find any evidence that home range size in the Willie Wagtail was influenced by patch type, size, or shape (Appendix S8). We found no effect of planting age on home range size in either the Superb Fairywren or the Willie Wagtail (Fig. 3).

The shape of Superb Fairywren home ranges was strongly dictated by patch shape in restoration plantings and similarly sized remnants (Table 7). Home ranges became more linear as the linearity of patches increased (Fig. 4). This trend was magnified in restoration plantings (Table 7; Fig. 5). We found no effect of patch type or planting age on shape of Superb Fairywren home ranges. The shape of Willie Wagtail home ranges was not influenced by patch attributes.

Movement distances.-On average, Superb Fairywrens moved $13 \mathrm{~m}$ between substrates $(n=4779, \mathrm{SE}=0.21)$, 
TABle 6. Parameter estimates for home range size of Superb Fairywrens, ranked by Akaike's Information Criterion adjusted for small sample sizes $\left(\mathrm{AIC}_{\mathrm{c}}\right)$.

\begin{tabular}{|c|c|c|c|}
\hline \multirow[b]{2}{*}{ Home range size } & \multicolumn{3}{|c|}{ Parameter estimate } \\
\hline & Rank 1 & Rank 2 & Rank 3 \\
\hline \multicolumn{4}{|l|}{ All site types $\dagger$} \\
\hline Intercept & $-1.44(0.12)$ & & \\
\hline TYPE (reference) & $0.79(0.34)$ & & \\
\hline TYPE (remnant) & $-0.10(0.26)$ & & \\
\hline \multicolumn{4}{|c|}{ Plantings and remnantsł } \\
\hline Intercept & $-2.02(0.21)$ & $-2.02(0.20)$ & $-1.87(0.25)$ \\
\hline SIZE & $0.17(0.05)$ & $0.19(0.06)$ & $0.16(0.06)$ \\
\hline TYPE (remnant) & & $-0.33(0.24)$ & \\
\hline SHAPE & & & $-0.003(0.002)$ \\
\hline \multicolumn{4}{|l|}{ Plantings only§ } \\
\hline Intercept & $-2.12(0.20)$ & $-2.06(0.20)$ & $-1.98(0.24)$ \\
\hline SIZE & $0.22(0.06)$ & $0.21(0.06)$ & $0.21(0.06)$ \\
\hline AGE & & $0.14(0.11)$ & \\
\hline SHAPE & & & $-0.003(0.003)$ \\
\hline
\end{tabular}

Notes: Top-ranked models $\left(\Delta \mathrm{AIC}_{\mathrm{c}} \leq 2\right)$ are shown for all site types (restoration planting, remnant, reference), restoration plantings and remnants, and restoration plantings only. All models that differed from the top model $\left(\Delta \mathrm{AIC}_{\mathrm{c}}\right)$ by $\leq 2$ are shown. SE is given in parentheses.

$\dagger$ Rank $1, \mathrm{w}=0.58$

$\ddagger$ Rank 1, w $=0.37 ; \operatorname{Rank} 2, \mathrm{w}=0.29 ; \operatorname{Rank} 3, \mathrm{w}=0.20$.

$\S$ Rank 1, w $=0.39 ; \operatorname{Rank} 2, \mathrm{w}=0.26 ; \operatorname{Rank} 3, \mathrm{w}=0.20$.

and Willie Wagtails moved $26 \mathrm{~m}(n=3154, \mathrm{SE}=0.59)$. We found no relationship between patch attributes and average movement distances of Superb Fairywrens or Willie Wagtails. However, we found that as patch linearity increased in plantings and similarly sized remnants, Superb Fairywrens were more likely to travel distances of $50 \mathrm{~m}$ or more in a single movement, and Willie Wagtails were more likely to travel $100 \mathrm{~m}$ or more in a single movement (Appendix S7). We also found that Willie Wagtails were more likely to move $100 \mathrm{~m}$ or more in plantings than in remnants or reference sites (Appendix S7).

\section{Gap-crossing}

We observed significant gap-crossing behavior in the Willie Wagtail. As predicted, individuals in linear sites crossed gaps more frequently than individuals in blockshaped sites. The maximum distance crossed by a single individual was $400 \mathrm{~m}$. This was between two linear restoration plantings on either side of a pasture paddock (Appendix S4: Fig. S1). The individual responsible for this particular observation crossed this gap twice in a 2$\mathrm{h}$ period, using an isolated paddock tree as a stepping stone on the return journey. Another individual crossed an $\sim 100-\mathrm{m}$ gap between two plantings 13 times during a roughly 3.5-h tracking period (Appendix S4: Fig. S2). Superb Fairywrens were not observed to cross habitat gaps of more than $35 \mathrm{~m}$ while foraging, and rarely crossed gaps at all during observation. However, over

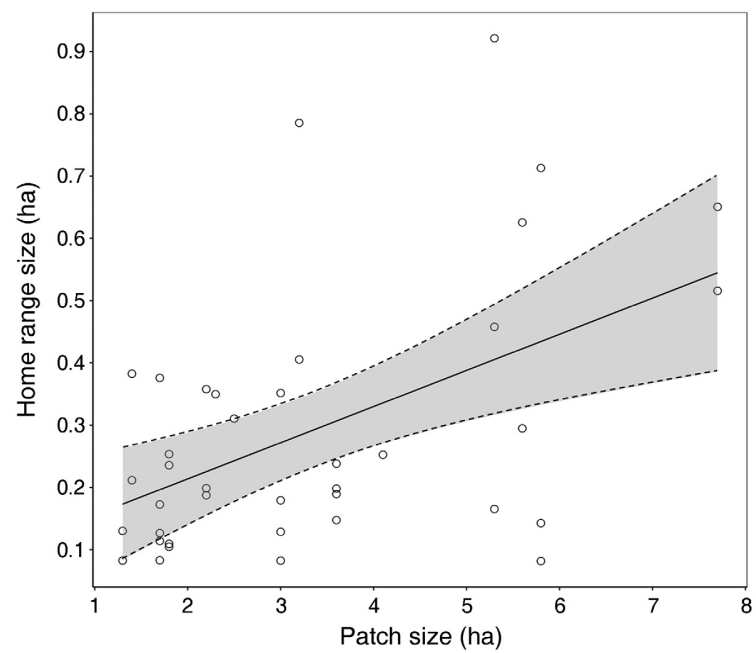

FIG. 2. The influence of patch size on home range size of adult male Superb Fairywrens (Malurus cyaneus) in restoration plantings and similarly sized woodland remnants. Shading indicates $95 \%$ confidence intervals. Plot constructed using ggplot 2 for R (Wickham 2016).

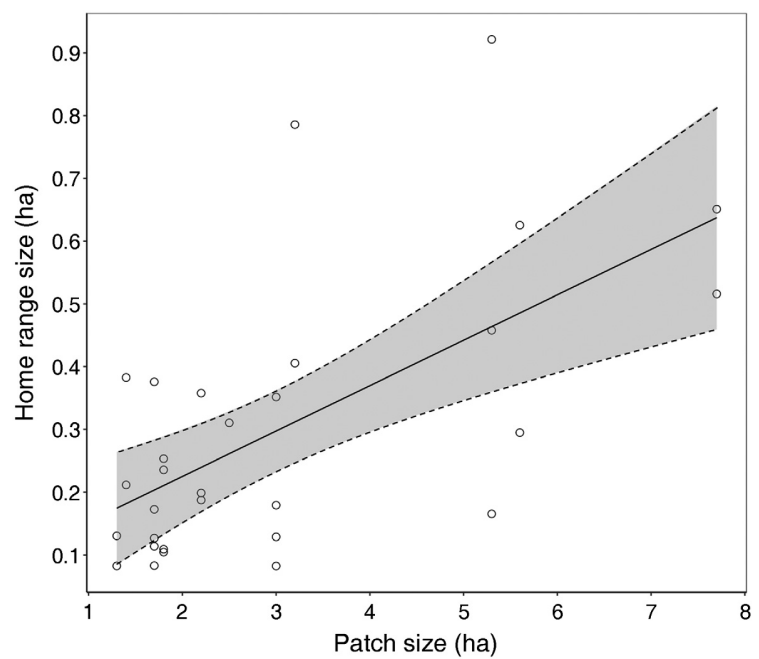

FIG. 3. The influence of patch size on home range size of adult male Superb Fairywrens (Malurus cyaneus) in restoration plantings. Shading indicates $95 \%$ confidence intervals. Plot constructed using ggplot2 for R (Wickham 2016).

the course of the study, we recorded several instances (six confirmed) of Superb Fairywrens dispersing from one study site to another (see examples in Appendix S5). These individuals would have crossed gaps of up to several hundred meters on the journey between sites.

\section{Discussion}

We calculated annual survival for woodland birds in a fragmented agricultural landscape, and documented new information on woodland bird home ranges and movement patterns in restoration plantings and woodland 
TABle 7. Parameter estimates for home range shape of Superb Fairywrens, ranked by $\mathrm{AIC}_{\mathrm{c}}$.

\begin{tabular}{lrr}
\hline \hline & \multicolumn{2}{c}{ Parameter estimate } \\
\cline { 2 - 3 } Home range size & \multicolumn{1}{c}{ Rank 1 } & Rank 2 \\
\hline Plantings and remnants $\dagger$ & & \\
$\quad$ Intercept & $3.69(0.62)$ & $3.39(0.62)$ \\
SHAPE & $0.05(0.01)$ & $0.04(0.01)$ \\
TYPE (remnant) & $-1.96(1.03)$ & \\
Plantings only $\neq$ & & \\
Intercept & $3.24(0.67)$ & \\
SHAPE & $0.06(0.01)$ & \\
\end{tabular}

Notes: Top-ranked models $\left(\Delta \mathrm{AIC}_{\mathrm{c}} \leq 2\right)$ are shown for restoration plantings and remnants, and restoration plantings only. All models that differed from the top model $\left(\Delta \mathrm{AIC}_{\mathrm{c}}\right)$ by $\leq 2$ are shown. SE is given in parentheses.

$\dagger$ Rank 1, w $=0.50 ;$ Rank 2, w $=0.27$.

$\ddagger$ Rank $1, \mathrm{w}=0.60$.

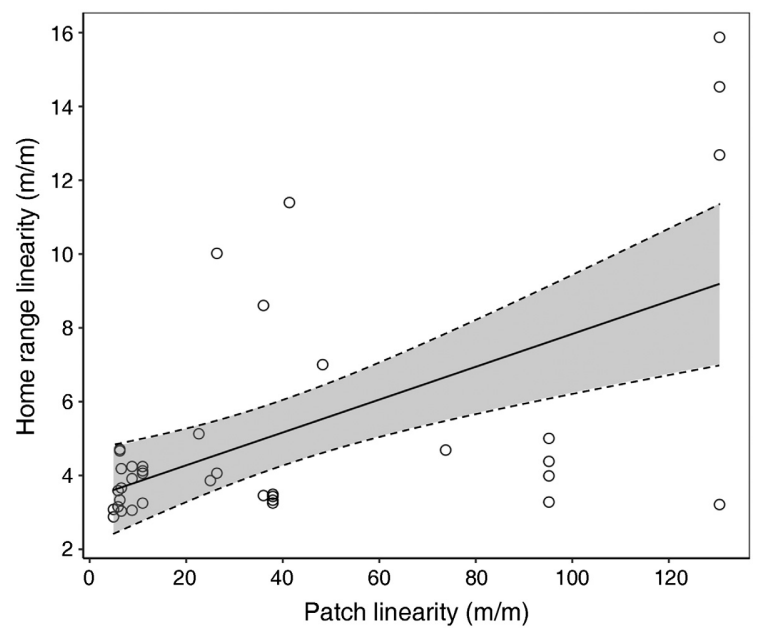

FIG. 4. The influence of patch shape on home range shape of adult male Superb Fairywrens (Malurus cyaneus) in restoration plantings and similarly sized woodland remnants. Shading indicates $95 \%$ confidence intervals. Plot constructed using ggplot2 for R (Wickham 2016).

remnants. We discuss our key findings in the remainder of this paper and conclude with some management implications.

Annual survival estimates for the woodland assemblage $(51 \%)$ and color-banded birds (55\%) were lower than expected. Other Australian studies have commonly reported survival estimates of above $60 \%$ for various woodland species in both intact landscapes (Yom-Tov et al. 1992, Bridges 1994, Dunn and Cockburn 1999, Green and Cockburn 1999, Gardner et al. 2003, Robinson 2008) and fragmented agricultural landscapes (Noske 1991, Zanette 2001, Brooker and Brooker 2001). Survival estimates for the Superb Fairywren (55\%) also were lower than those reported in some previous studies (Yom-Tov et al. 1992, Dunn and Cockburn 1999), but within the range reported by Baker et al. (1997). Overall, the ostensibly low rate of annual survival in our study

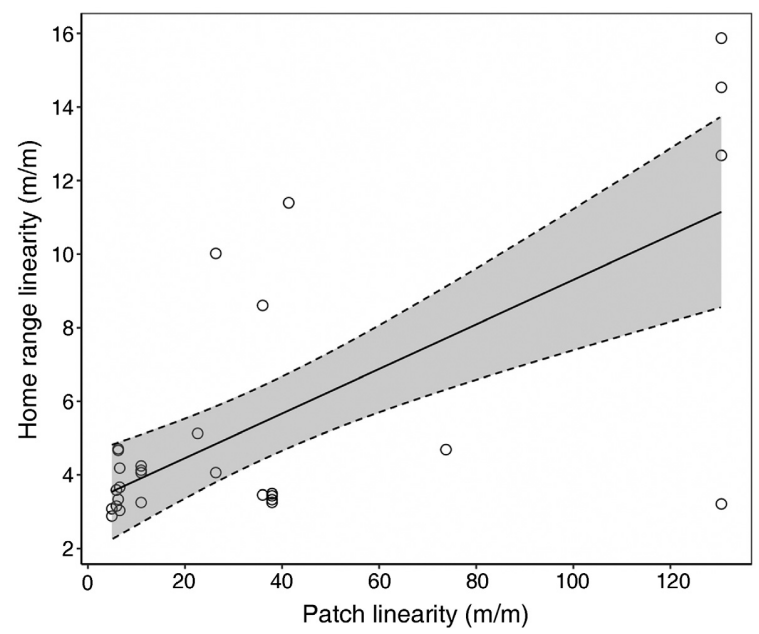

FIG. 5. The influence of patch shape on home range shape of adult male Superb Fairywrens (Malurus cyaneus) in restoration plantings. Shading indicates $95 \%$ confidence intervals. Plot constructed using ggplot2 for R (Wickham 2016).

sites is concerning, and raises questions about the extent to which restoration plantings are currently contributing to the arresting (and eventual reversal) of woodland bird population declines.

It is possible that restoration plantings act as secondary or transitional habitat for woodland birds, and that retention (and thus apparent survival) of individuals in small patches of revegetation may be poor. However, previous research has shown that various species breed in plantings (Belder et al. 2019, 2020b), indicating that populations are resident to at least some degree. Annual survival may otherwise be influenced by a range of possible factors, which we were unable to isolate during our study. One potential factor driving low annual survival is the presence of high numbers of predators, especially the introduced red fox (Vulpes vulpes), in fragmented agricultural landscapes (Ford et al. 2001, Saunders et al. 2010, Belder et al. 2020b).

Unreliable estimates of site fidelity were likely due the low number of capture occasions in our study (J. Laake, personal communication). However, we note the high return rate for the Rufous Whistler, with several colorbanded males returning in consecutive years to defend territories at their initial capture sites. High interannual site fidelity has been previously observed in this species in temperate woodlands (Bridges 1994). Our findings are evidence that restoration plantings provide high-quality breeding habitat for Rufous Whistlers.

Question 1. Do patch attributes (type, size, shape) influence survival and site fidelity of woodland birds in fragmented agricultural landscapes?

We did not find strong evidence that site attributes influenced the survival of woodland birds. We postulate that survival may instead be linked to factors that we did 
not consider in our study, such as predation risk, landscape-scale vegetation cover, connectivity, or climatic variables (Major and Gowing 2001, Whittingham and Evans 2004, Radford et al. 2005, Robinson et al. 2007, Shanahan et al. 2011).

\section{Question 2. How do patch attributes influence the movement patterns of birds, including the size and shape of home ranges?}

The average home range size for Superb Fairywrens ( 0.37 ha) was smaller than previously reported for the species in fragmented rural habitat (Tidemann 1983, Parsons 2009), and comparable with that reported by Mulder (1992) in high-quality woodland habitat. Previous research has identified that this species is a "planting specialist," and will preferentially occupy restoration plantings over other kinds of habitat in fragmented agricultural landscapes (Belder et al. 2018). It is possible that the home range sizes we observed in our study indicate that restoration plantings provide good quality habitat for the Superb Fairywren. However, a small home range in a fragmented landscape may also be indicative of reduced foraging efficiency associated with low habitat availability (Hinam and Clair 2008). This may also explain why the home range size of the Superb Fairywren was positively associated with patch size: larger sites permit the expansion of home ranges. Previous research has documented more bird breeding activity in smaller plantings and woodland remnants (Belder et al. 2019). Superb Fairywren home ranges in smaller patches may also be constrained by higher densities of breeding individuals.

We could find only one published study reporting on the average home range size of Willie Wagtails: breeding pairs in Papua New Guinea occupied average home ranges of 0.85 ha (Dyrcz 1994). This is substantially smaller than the average home range size of Willie Wagtails in our study (2.07 ha), and may be linked to the intactness of the landscape in which the study took place. We suggest that Willie Wagtails in our study maintained larger home ranges than they would in intact landscapes. The significant gap-crossing behavior that we observed (discussed further in subsequent paragraphs) is further evidence of this.

Superb Fairywrens that resided in linear sites had much more elongate home ranges than those in blockshaped sites. According to optimal foraging theory, an elongate home range does not facilitate optimal foraging: as the maximum distance from a central point increases, so too does the energy required to reach that point (Andersson 1978, Pyke 2010). It is also more difficult for an individual to patrol and defend an elongate territory, as the outer extremities are further away from the core of the territory (Dill 1978). Both Superb Fairywrens and Willie Wagtails were more likely to travel long distances between substrates while foraging in linear sites, evidence that energy expenditure is indeed higher in these sites than in block-shaped sites. We suggest that linear sites constrain the home range shape of woodland birds, potentially placing individuals in these patches at a disadvantage compared to individuals in block-shaped sites. This is particularly relevant for breeding birds, although previous research has found no effect of patch linearity on breeding success (Belder et al. 2019; unpublished data).

Previous studies have found that linear sites support lower overall species richness and abundance than similarly sized block-shaped sites (Lindenmayer et al. $2010 b$ ). Our results add weight to the idea that blockshaped sites better support woodland birds than linear sites. However, we acknowledge the importance of linear sites in improving landscape connectivity in fragmented agricultural landscapes (Schippers et al. 2009, Lentini et al. 2011). Furthermore, intersecting linear patches have been found to support similar species richness and abundance to block-shaped sites (Lindenmayer et al. 2007). These findings highlight the need to consider the context and geographical location of restoration plantings in conservation planning. For instance, it may be beneficial to establish new plantings near to existing vegetation, widen linear strips, fill in corners where strips meet, or link small remnants.

The gap-crossing behavior that we documented in the Willie Wagtail is also of interest in the context of restoration planting configuration in fragmented agricultural landscapes. For individuals that frequently cross large habitat gaps, a high proportion of the territory is matrix habitat (pasture or cropland), and unsuitable for foraging. These individuals therefore expend considerably more energy commuting between areas of highquality habitat within their home range than do individuals who maintain home ranges entirely or mostly within a single habitat patch. Previous research has identified that woodland birds needing to cross large habitat gaps experience lower reproductive success and output (Hinsley et al. 2008). The configuration and isolation of many restoration plantings may increase the energy expenditure of breeding birds, and therefore add to the existing pressures that breeding birds face in these landscapes. Furthermore, species that are unwilling or unable to cross large habitat gaps are likely to be disadvantaged by a lack of landscape connectivity (Brooker et al. 1999, Lees and Peres 2009, Garrard et al. 2012). Poor landscape connectivity has been linked to local extinctions of woodland and forest bird species (Bellamy et al. 1996, Uezu et al. 2005, Doerr et al. 2011, Pavlacky et al. 2012).

Willie Wagtails visited scattered paddock trees within the agricultural matrix, particularly while crossing habitat gaps. Such behavior has been observed in other small to medium-sized woodland birds in fragmented landscapes (Fischer and Lindenmayer 2002a, Robertson and Radford 2009). Paddock trees (and other isolated habitat features) facilitate connectivity in fragmented agricultural landscapes (Manning et al. 2006). These features are of disproportionate importance in ensuring the 
persistence of fauna populations in these landscapes (Gibbons and Boak 2002, Le Roux et al. 2015, 2018).

\section{Inferential limitations and future research directions}

This study provides novel insights into survival and home ranges of woodland birds in fragmented agricultural landscapes. However, we note the short duration of the study and low number of physical recapture efforts per site, and acknowledge that long-term trends cannot be forecast from a study of only three years. Furthermore, we are unable to infer the causes of an apparently high rate of annual turnover; it is unclear whether this was caused by emigration, mortality, or a combination of the two processes. The presence of site attributes in top-ranked survival models indicates that these variables may influence survival to some degree. Alternatively, factors outside the scope of this study may be more influential. Future research should focus on investigating this.

We encourage researchers to undertake long-term bird banding studies in fragmented agricultural landscapes. While banding requires considerable resources and effort, it provides invaluable information on the survival, movement, persistence, and activities of individual birds and their populations. A national network of banding projects would improve understanding of bird movements and demographic processes. Advancements in telemetry techniques may facilitate the collection of these data in the future.

We also suggest conducting home range and movement studies on a wider range of woodland bird species, especially those that may be more dependent on tree cover.

\section{Concluding remarks}

The value of small habitat patches for biodiversity conservation has been well documented and reviewed (Fischer and Lindenmayer 2002b, Tulloch et al. 2016, Lindenmayer 2019, Wintle et al. 2019). Restoration plantings provide habitat that is complementary to existing woodland remnants (Ikin et al. 2018), and in which birds can breed successfully (Belder et al. 2020b). There is no doubt that restoration plantings are a necessary conservation strategy in fragmented agricultural landscapes. However, the results of our study indicate that (1) patch isolation and certain patch configurations place resident and breeding birds at an energetic disadvantage, and (2) in our study area, woodland bird populations are continuing to decline, and poor annual survival may contribute to this. Urgent action is needed to restore habitat at a landscape scale if we are to avoid ongoing losses and local extinctions of woodland birds in southern Australia.

\section{ACKNOWLEDGMENTS}

We are grateful for the feedback of two anonymous reviewers, which helped improve an earlier version of this manuscript.
This work was undertaken with approval from the Australian Bird and Bat Banding Scheme and the Australian National University's Animal Ethics and Experimentation Committee, and under NSW Scientific Research Licence \#SL101588. Richard Donaghey was the A-class banding project coordinator, and we are grateful for his assistance. The collection of home range data was greatly assisted by the contributions of Matt Gale and Ira Dudley-Bestow. We thank the many volunteers who assisted with bird banding: Richard Allen, Cat Young, Mark Clayton, Lachlan Duncan, Damian Lettoof, Jas Allnutt, Ann-Elise Gimpel, Nick Shore, Gary Belder, Lyn Belder, Emma Belder, Tom Bradley, Joel Allan, Jamey Creighton, Ding Li Yong, Brenton von Takach Dukai, and Hayden Stevens. We are grateful to Lyn Belder for assisting with data entry. We also thank the landowners who permitted access to their properties. This work was funded by the Riverina Local Land Services via a research grant to D. B. Lindenmayer, and a Margaret Middleton Fund Award, Lesslie Scholarship, and Australian Bird Study Association small research grant to D. J. Belder. Funding was also contributed by the Threatened Species Recovery Hub (via the Australian Government's National Environmental Science Program).

\section{Literature Cited}

Andersson, M. 1978. Optimal foraging area: Size and allocation of search effort. Theoretical Population Biology 13:397-409.

Andersson, M. 1981. Central place foraging in the Whinchat, Saxicola rubetra. Ecology 62:538-544.

Australian Bird and Bat Banding Scheme. 2016. ABBBS Database. Canberra, Australian Capital Territory, Australia. https://www.environment.gov.au/topics/science-and-research/ bird-and-bat-banding/banding-data/search-abbbs-database

Baker, G. B., E. B. Dettmann, and S. J. Wilson. 1997. Fire and its impact on avian population dynamics. Pacific Conservation Biology 3:206-212.

Barbour, A. B., J. M. Ponciano, and K. Lorenzen. 2013. Apparent survival estimation from continuous mark-recapture/resighting data. Methods in Ecology and Evolution 4:846-853.

Barker, R. J. 1997. Joint modeling of live-recapture, tag-resight, and tag-recovery data. Biometrics 53:666-677.

Barnosky, A. D., et al. 2011. Has the Earth's sixth mass extinction already arrived? Nature 471:51-57.

Barral, M. P., J. M. Rey Benayas, P. Meli, and N. O. Maceira. 2015. Quantifying the impacts of ecological restoration on biodiversity and ecosystem services in agroecosystems: A global meta-analysis. Agriculture, Ecosystems \& Environment 202:223-231.

Barrett, G. W., D. Freudenberger, A. Drew, J. Stol, A. O. Nicholls, and E. M. Cawsey. 2008. Colonisation of native tree and shrub plantings by woodland birds in an agricultural landscape. Wildlife Research 35:19-32.

Bartoń, K. 2018. MuMIn: Multi-Model Inference. https://www. google.com/search?rlz=1C1GGRV_enAU795AU795\&sxsrf= ALeKk011JE_eFmoEC3_1_gO6n-eNX0x8pA\%3A161033120 3834\&ei=Q7T7X926MuaV4-EPwamCmA4\&q=barton $\% 2 \mathrm{C}$ $+\mathrm{K} .+$ mumin $+2018 \&$ oq $=$ barton $\% 2 \mathrm{C}+\mathrm{K} .+$ mumin $+2018 \&$ gs_lcp $=\mathrm{CgZwc} 3 \mathrm{ktYWIQAzoECCMQJzoH}$

Bates, D., M. Maechler, B. Bolker, and S. Walker. 2015. Fitting Linear Mixed-Effects Models Using lme4. Journal of Statistical Software 67:1-48.

Battin, J. 2004. When good animals love bad habitats: Ecological traps and the conservation of animal populations. Conservation Biology 18:1482-1491.

Beggs, R., A. I. T. Tulloch, J. Pierson, W. Blanchard, M. Crane, and D. Lindenmayer. 2019. Patch-scale culls of an 
overabundant bird defeated by immediate recolonization. Ecological Applications 29:e01846.

Belder, D., D. Lindenmayer, J. Pierson, and A. Rudder. $2020 a$ Survival and home ranges of woodland birds in restoration plantings. Dryad, data set. https://doi.org/10.5061/dryad. m0cfxpp2b

Belder, D. J., J. C. Pierson, K. Ikin, W. Blanchard, M. J. Westgate, M. J. Crane, and D. B. Lindenmayer. 2019. Is bigger always better? Influence of patch attributes on breeding activity of birds in box-gum grassy woodland restoration plantings. Biological Conservation 236:134-152.

Belder, D. J., J. C. Pierson, K. Ikin, and D. B. Lindenmayer 2018. Beyond pattern to process: Current themes and future directions for the conservation of woodland birds through restoration plantings. Wildlife Research 45:473-489.

Belder, D. J., J. C. Pierson, K. Ikin, and D. B. Lindenmayer. $2020 \mathrm{~b}$. Revegetation and reproduction: do restoration plantings in agricultural landscapes support breeding populations of woodland birds? Oecologia 192:865-878.

Bellamy, P. E., S. A. Hinsley, and I. Newton. 1996. Local extinctions and recolonisations of passerine bird populations in small woods. Oecologia 108:64-71.

Bennett, J. M., R. H. Clarke, J. R. Thomson, and R. Mac Nally. 2015. Fragmentation, vegetation change and irruptive competitors affect recruitment of woodland birds. Ecography $38: 163-171$.

Benson, J. 2013. New South Wales Vegetation Classification and Assessment: Part 2, plant communities of the NSW South-western Slopes Bioregion and update of NSW Western Plains plant communities, Version 2 of the NSWVCA database. Cunninghamia 10:599-673.

Bridges, L. 1994. Territory and mate fidelity in a migratory population of the Rufous Whistler Pachycephala rufiventris. Emu 94:156-165.

Brooker, L., M. Brooker, and P. G. Cale. 1999. Animal dispersal in fragmented habitat: measuring habitat connectivity, corridor use, and dispersal mortality. Conservation Ecology $3: 1-22$.

Brooker, M., and L. Brooker. 2001. Breeding biology, reproductive success and survival of blue-breasted fairy-wrens in fragmented habitat in the Western Australian wheatbelt. Wildlife Research 28:205-214.

Bureau of Meteorology. 2019. Climate Statistics for Australian Locations. Bureau of Meteorology, Melbourne, Australia. http://www.bom.gov.au/climate/data/

Ceballos, G., P. R. Ehrlich, A. D. Barnosky, A. García, R. M. Pringle, and T. M. Palmer. 2015. Accelerated modern human-induced species losses: Entering the sixth mass extinction. Science Advances 1:e1400253.

Cunningham, R. B., D. B. Lindenmayer, M. J. Crane, D. R. Michael, C. I. MacGregor, R. M. Montague-Drake, and J. Fischer. 2008. The combined effects of remnant vegetation and tree planting on farmland birds. Conservation Biology $22: 742-752$

Cunningham, S. C., R. Mac Nally, P. J. Baker, T. R. Cavagnaro, J. Beringer, J. R. Thomson, and R. M. Thompson. 2015 Balancing the environmental benefits of reforestation in agricultural regions. Perspectives in Plant Ecology, Evolution and Systematics 17:301-317.

Department of the Environment and Energy. 2018. White BoxYellow Box-Blakely's Red Gum Grassy Woodland and Derived Native Grassland in Community and Species Profile and Threats Database. http://www.environment.gov.au/sprat

Dias, P. C. 1996. Sources and sinks in population biology. Trends in Ecology \& Evolution 11:326-330.

Dill, L. M. 1978. An energy-based model of optimal feedingterritory size. Theoretical Population Biology 14:396-429.
Doerr, V. A. J., E. D. Doerr, and M. J. Davies. 2011. Dispersal behaviour of Brown Treecreepers predicts functional connectivity for several other woodland birds. Emu 111:71-83.

Driscoll, D. A., L. M. Bland, B. A. Bryan, T. M. Newsome, E. Nicholson, E. G. Ritchie, and T. S. Doherty. 2018. A biodiversity-crisis hierarchy to evaluate and refine conservation indicators. Nature Ecology \& Evolution 2:775-781.

Dunn, P. O., and A. Cockburn. 1999. Extrapair mate choice and honest signaling in cooperatively breeding superb fairywrens. Evolution 53:938-946.

Dyrcz, A. 1994. Breeding biology and behaviour of the Willie Wagtail Rhipidura leucophrys in the Madang region, Papua New Guinea. Emu 94:17-26.

ESRI. 2018. ArcGIS Desktop: 10.6.1. Environmental Systems Research Institute, Redlands, California, USA.

Fischer, J., and D. B. Lindenmayer. 2002a. The conservation value of paddock trees for birds in a variegated landscape in southern New South Wales. 2. Paddock trees as stepping stones. Biodiversity and Conservation 11:833-849.

Fischer, J., and D. B. Lindenmayer. 2002b. Small patches can be valuable for biodiversity conservation: two case studies on birds in southeastern Australia. Biological Conservation 106:129-136.

Ford, H. A., G. W. Barrett, D. A. Saunders, and H. F. Recher. 2001. Why have birds in the woodlands of Southern Australia declined? Biological Conservation 97:71-88.

Ford, R. G. 1983. Home range in a patchy environment: optimal foraging predictions. American Zoologist 23:315-326.

Freudenberger, D. 2001. Bush for the birds: Biodiversity enhancement guidelines for the Saltshaker Project, Boorowa, NSW. Consultancy report to Greening Australia ACT \& SE NSW, Inc. CSIRO Sustainable Ecosystems, Canberra, Australian Capital Territory, Australia.

Freudenberger, D., J. Harvey, and A. Drew. 2004. Predicting the biodiversity benefits of the Saltshaker Project, Boorowa, NSW. Ecological Management \& Restoration 5:5-14.

Gardner, J. L., R. D. Magrath, and H. Kokko. 2003. Stepping stones of life: Natal dispersal in the group-living but noncooperative speckled warbler. Animal Behaviour 66:521-530

Garrard, G. E., M. A. McCarthy, P. A. Vesk, J. Q. Radford, and A. F. Bennett. 2012. A predictive model of avian natal dispersal distance provides prior information for investigating response to landscape change. Journal of Animal Ecology $81: 14-23$

Gibbons, P., and M. Boak. 2002. The value of paddock trees for regional conservation in an agricultural landscape. Ecological Management \& Restoration 3:205-210.

Green, D. J., and A. Cockburn. 1999. Life history and demography of an uncooperative Australian passerine, the brown thornbill. Australian Journal of Zoology 47:633-649.

Hinam, H. L., and C. C. S. Clair. 2008. High levels of habitat loss and fragmentation limit reproductive success by reducing home range size and provisioning rates of Northern saw-whet owls. Biological Conservation 141:524-535.

Hinsley, S. A., R. A. Hill, P. E. Bellamy, N. M. Harrison, J. R. Speakman, A. K. Wilson, and P. N. Ferns. 2008. Effects of structural and functional habitat gaps on breeding woodland birds: working harder for less. Landscape Ecology 23:615-626.

Ikin, K., A. I. T. Tulloch, D. Ansell, and D. B. Lindenmayer. 2018. Old growth, regrowth, and planted woodland provide complementary habitat for threatened woodland birds on farms. Biological Conservation 223:120-128.

Kacelnik, A. 1984. Central place foraging in starlings (Sturnus vulgaris). I. Patch residence time. Journal of Animal Ecology $53: 283-299$ 
Kahle, D., and H. Wickham. 2013. ggmap: Spatial Visualization with ggplot2. R Journal 5:144-161.

Kauffman, M. J., W. F. Frick, and J. Linthicum. 2003. Estimation of habitat-specific demography and population growth for Peregrine Falcons in California. Ecological Applications 13:1802-1816.

Laake, J. L. 2013. RMark: An R interface for analysis of capture-recapture data with MARK. Alaska Fisheries Science Center, and National Marine Fisheries Service, Seattle, Washington, USA.

Le Roux, D. S., K. Ikin, D. B. Lindenmayer, A. D. Manning, and P. Gibbons. 2015. Single large or several small? Applying biogeographic principles to tree-level conservation and biodiversity offsets. Biological Conservation 191:558-566.

Le Roux, D. S., K. Ikin, D. B. Lindenmayer, A. D. Manning, and P. Gibbons. 2018. The value of scattered trees for wildlife: Contrasting effects of landscape context and tree size. Diversity and Distributions 24:69-81.

Lebreton, J.-D., K. P. Burnham, J. Clobert, and D. R. Anderson. 1992. Modeling survival and testing biological hypotheses using marked animals: a unified approach with case studies. Ecological Monographs 62:67-118.

Lees, A. C., and C. A. Peres. 2009. Gap-crossing movements predict species occupancy in Amazonian forest fragments. Oikos 118:280-290.

Lehnen, S. E., and A. D. Rodewald. 2009. Dispersal, interpatch movements, and survival in a shrubland breeding bird community. Journal of Field Ornithology 80:242-252.

Lentini, P. E., J. Fischer, P. Gibbons, J. Hanspach, and T. G. Martin. 2011. Value of large-scale linear networks for bird conservation: a case study from travelling stock routes, Australia. Agriculture, Ecosystems \& Environment 141:302-309.

Lindenmayer, D. B. 2017. Conserving large old trees as small natural features. Biological Conservation 211:51-59.

Lindenmayer, D. B. 2019. Small patches make critical contributions to biodiversity conservation. Proceedings of the National Academy of Sciences USA 116:717-719.

Lindenmayer, D. B., A. F. Bennett, and R. J. Hobbs. 2010a. An overview of the ecology, management and conservation of Australia's temperate woodlands. Ecological Management \& Restoration 11:201-209.

Lindenmayer, D. B., R. B. Cunningham, M. J. Crane, D. R. Michael, and R. M. Montague-Drake. 2007. Farmland bird responses to intersecting replanted areas. Landscape Ecology 22:1555-1562.

Lindenmayer, D. B., E. J. Knight, M. J. Crane, R. M. Montague-Drake, D. R. Michael, and C. I. MacGregor. $2010 b$. What makes an effective restoration planting for woodland birds? Biological Conservation 143:289-301.

Lindenmayer, D. B., D. Michael, M. Crane, and D. Florance. 2018. Ten lessons in 20 years: Insights from monitoring fauna and temperate woodland revegetation. Ecological Management and Restoration 19:36-43.

Lindenmayer, D. B., E. Willinck, M. J. Crane, D. R. Michael, S. Okada, C. Cumming, K. Durant, and J. Frankenberg. 2013. Murray Catchment habitat restoration: Lessons from landscape-level research and monitoring. Ecological Management \& Restoration 14:80-92.

Major, R. E., and G. Gowing. 2001. Survival of red-capped robins (Petroica goodenovii) in woodland remnants of central western New South Wales, Australia. Wildlife Research 28:565-571.

Manning, A. D., J. Fischer, and D. B. Lindenmayer. 2006. Scattered trees are keystone structures-implications for conservation. Biological Conservation 132:311-321.

Maron, M., M. J. Grey, C. P. Catterall, R. E. Major, D. L. Oliver, M. F. Clarke, R. H. Loyn, R. Mac Nally, I. Davidson, and J. R. Thomson. 2013. Avifaunal disarray due to a single despotic species. Diversity and Distributions 19:1468-1479.

McKibbin, R., and C. A. Bishop. 2012. Site fidelity and annual survival of the western Yellow-breasted Chat (Icteria virens auricollis) at the northern edge of its range. Canadian FieldNaturalist 126:135-142.

Meager, J., E. Hawkins, I. Ansmann, and G. Parra. 2018. Longterm trends in habitat use and site fidelity by Australian humpback dolphins Sousa sahulensis in a near-urban embayment. Marine Ecology Progress Series 603:227-242.

Menkhorst, P., D. Rogers, R. Clarke, J. Davies, P. Marsack, and K. Franklin. 2017. The Australian Bird Guide. CSIRO Publishing, Canberra, Australian Capital Territory, Australia.

Menz, M. H. M., K. W. Dixon, and R. J. Hobbs. 2013. Hurdles and opportunities for landscape-scale restoration. Science 339:526-527.

Molotoks, A., E. Stehfest, J. Doelman, F. Albanito, N. Fitton, T. P. Dawson, and P. Smith. 2018. Global projections of future cropland expansion to 2050 and direct impacts on biodiversity and carbon storage. Global Change Biology 24:5895-5908.

Mulder, R. A. 1992. Evolutionary ecology of the mating system of superb fairy-wrens. Thesis. Australian National University, Canberra, Australian Capital Territory, Australia.

Newbold, T., et al. 2015. Global effects of land use on local terrestrial biodiversity. Nature 520:45-50.

Noske, R. A. 1991. A demographic comparison of cooperatively breeding and non-cooperative treecreepers (Climacteridae). Emu 91:73-86.

Parsons, H. M. 2009. The effect of urbanisation on the superb fairy-wren (Malurus cyaneus). Thesis. University of Wollongong, Wollongong, Australia.

Pavlacky, D. C., H. P. Possingham, A. J. Lowe, P. J. Prentis, D. J. Green, and A. W. Goldizen. 2012. Anthropogenic landscape change promotes asymmetric dispersal and limits regional patch occupancy in a spatially structured bird population. Journal of Animal Ecology 81:940-952.

Pyke, G. H. 2010. Optimal foraging theory. Pages 2561-2566inM. D. Breed and J. Moore, editors. Encyclopedia of animal behavior. First edition. Academic Press, Amsterdam, The Netherlands.

R Core Team. 2019. R: A language and environment for statistical computing. R Foundation for Statistical Computing, Vienna, Austria. www.R-project.org

Radford, J. Q., A. F. Bennett, and G. J. Cheers. 2005. Landscape-level thresholds of habitat cover for woodland-dependent birds. Biological Conservation 124:317-337.

Rayner, L., D. B. Lindenmayer, P. Gibbons, and A. D. Manning. 2014. Evaluating empirical evidence for decline in temperate woodland birds: A nationally threatened assemblage of species. Biological Conservation 171:145-155.

Robertson, O. J., and J. Q. Radford. 2009. Gap-crossing decisions of forest birds in a fragmented landscape. Austral Ecology 34:435-446.

Robinson, D. 2008. The social organization of the Scarlet Robin Petroica multicolor and Flame Robin P. phoenicea in southeastern Australia: a comparison between sedentary and migratory flycatchers. Ibis 132:78-94.

Robinson, R. A., S. R. Baillie, and H. Q. P. Crick. 2007. Weather-dependent survival: Implications of climate change for passerine population processes. Ibis 149:357-364.

Rosenberg, D. K., and K. S. McKelvey. 2016. Estimation of habitat selection for central-place foraging animals. Journal of Wildlife Management 63:1028-1038.

Saunders, G. R., M. N. Gentle, and C. R. Dickman. 2010. The impacts and management of foxes Vulpes vulpes in Australia. Mammal Review 40:181-211. 
Schippers, P., C. J. Grashof-Bokdam, J. Verboom, J. M. Baveco, R. Jochem, H. A. M. Meeuwsen, and M. H. C. Van Adrichem. 2009. Sacrificing patches for linear habitat elements enhances metapopulation performance of woodland birds in fragmented landscapes. Landscape Ecology 24:1123-1133.

Schlossberg, S. 2009. Site fidelity of shrubland and forest birds. Condor 111:238-246.

Schwarzer, A. C., J. A. Collazo, L. J. Niles, J. M. Brush, N. J. Douglass, and H. F. Percival. 2012. Annual survival of Red Knots (Calidris canutus rufa) wintering in Florida. Auk 129:725-733.

Shanahan, D. F., C. Miller, H. P. Possingham, and R. A. Fuller. 2011. The influence of patch area and connectivity on avian communities in urban revegetation. Biological Conservation 144:722-729.

Stephens, D. W. 2008. Optimal foraging theory. Pages 2561-2566 in S. E. Jørgensen, and B. D. Fath, editors. Encyclopedia of ecology. Academic Press, Amsterdam, The Netherlands.

Tidemann, S. C. 1983. The behavioural ecology of three co-existing fairy-wren (Maluridae: Malurus). Thesis. Australian National University, Canberra, Australian Capital Territory, Australia.

Tulloch, A. I. T., M. D. Barnes, J. Ringma, R. A. Fuller, and J. E. M. Watson. 2016. Understanding the importance of small patches of habitat for conservation. Journal of Applied Ecology 53:418-429.
Uezu, A., J. P. Metzger, and J. M. E. Vielliard. 2005. Effects of structural and functional connectivity and patch size on the abundance of seven Atlantic Forest bird species. Biological Conservation 123:507-519.

Van Houtan, K. S., S. L. Pimm, J. M. Halley, R. O. Bierregaard, and T. E. Lovejoy. 2007. Dispersal of Amazonian birds in continuous and fragmented forest. Ecology Letters 10:219-229.

White, G. C., and K. P. Burnham. 1999. Program MARK: survival estimation from populations of marked animals. Bird Study 46:120-139.

Whittingham, M. J., and K. L. Evans. 2004. The effects of habitat structure on predation risk of birds in agricultural landscapes. Ibis 146:210-220.

Wickham, H. 2016. ggplot2: Elegant graphics for data analysis. Springer-Verlag, New York, New York, USA.

Wintle, B. A., et al. 2019. Global synthesis of conservation studies reveals the importance of small habitat patches for biodiversity. Proceedings of the National Academy of Sciences USA 116:909-914.

Yom-Tov, Y., R. McCleery, and D. Purchase. 1992. The survival rate of Australian passerines. Ibis 134:374-379.

Zanette, L. 2001. Indicators of habitat quality and the reproductive output of a forest songbird in small and large fragments. Journal of Avian Biology 32:38-46.

\section{SUPPORTING INFORMATION}

Additional supporting information may be found online at: http://onlinelibrary.wiley.com/doi/10.1002/eap.2268/full

Data Availability

Data are available from the Dryad Digital Repository (Belder, et al. 2020a): https://doi.org/10.5061/dryad.m0cfxpp2b 